\title{
Competitive strategies in soft corals (Coelenterata, Octocorallia). IV. Environmentally induced reversals in competitive superiority
}

\author{
Porfirio M. Alino ${ }^{1, *}$, Paul W. Sammarco ${ }^{2, * *}$, John C. Coll ${ }^{1, * * *}$ \\ ${ }^{1}$ Department of Chemistry and Biochemistry, James Cook University of North Queensland, Townsville, Queensland 4811, Australia \\ ${ }^{2}$ Australian Institute of Marine Science, P.M.B. No. 3, Townsville M.C., Queensland 4810, Australia
}

\begin{abstract}
Long-term evidence has demonstrated that an inshore reef (Pandora Reef) in the central region of the Great Barrier Reef, Australia, is becoming increasingly dominated by octocorals. To examine the effects of the local environmental setting on the outcome of competition for space, pairs of octocoral and scleractinian corals actively competing for space were transplanted from this inshore reef to a mid-shelf one (Britomart) in a controlled experiment. The 2 areas differ in their physical characteristics and biological communities. Competition for space between Clavularia inflata (Coelenterata, Octocorallia), Briareum stechei (Octocorallia), and Acropora longicyathus (Coelenterata, Scleractinia) in all possible pairs was assessed. Controls included undisturbed paired and solo colonies in their natural environment. A second set of corals was relocated to the mid-shelf and returned to its original environment as a control for handling effects. Competitive advantage was estimated via growth rate. Frequency of overgrowth, tissue necrosis, whole colony mortality, and tissue bleaching were also monitored. In their natural environment, Clavularia and Briareum were competitively superior to Acropora. Briareum was superior to Clavularia. With respect to mid-shelf transplants: the competitive edge of Clavularia over Acropora was reversed; the advantage of Briareum over Clavularia was reduced; and the advantage of Briareum over Acropora remained unchanged. On the mid-shelf, transplanted Acropora and Clavularia controls both suffered high mortality due to increased predation and, in the former, apparently increased light penetration. The growth rate of Briareum increased on the midshelf. Competitive relationships between these species are complex and can be modified by environmental factors. The refuge of the branching coral A. longicyathus on Pandora Reef was its marginally higher growth rate. Most other coral species at the study site, particularly the massives, appear to have succumbed to octocoral growth. Competitive advantage in some octocorals is apparently enhanced in inshore waters of the Great Barrier Reef in the presence of nutrient enrichment and lower levels of predation and light. Changes in local environmental factors in these inshore waters may be contributing to the observed increasing domination of Pandora Reef by octocorals.
\end{abstract}

\section{INTRODUCTION}

Competition is known to be a major selective force in structuring benthic marine communities (Levinton 1982. Connell 1983, Branch 1984). In particular, com-

Present addresses:

- Marine Science Institute, University of the Philippines at Diliman, Quezon City, Philippines

- Louisiana Universities Marine Consortium (LUMCON), Chauvin, Louisiana 70344, USA

... Chancellory University College of Central Queensland, Rockhampton, Qld. 4702, Australia (address for related correspondence) petition for space has been demonstrated repeatedly to serve as a limiting factor for population growth in sessile marine epibiota (Jackson 1977). Competition of this type can be strong enough to cause total local exclusion of species (Hughes 1986, Hughes et al. 1987).

A host of offensive and defensive strategies have evolved in relation to this selective force, varying widely in effectiveness between species. These include simple overgrowth (e.g, bryozoans; Buss 1979), extracoelenteric digestion via mesenterial filaments (e.g. scleractinian corals: Lang 1971, Sheppard 1982. Chornesky 1989, Lang \& Chornesky 1990), induced development of sweeper tentacles (e.g. scleractinian 
corals: Richardson et al. 1979, Wellington 1980, Bak et al. 1982; gorgonian corals: Sebens \& Miles 1988), and directed growth apparently in response to chemical stimuli (e.g. hydrozoans: Wahle 1980).

Another adaptation effective in competition for space is allelopathy - 'the direct inhibition of one species by another using noxious or toxic chemicals' (Muller 1966, Ricklefs 1979). Evidence suggesting the presence of allelopathic interactions in benthic communities was offered by Jackson \& Buss (1975). Experimental evidence confirming such interactions now exists for such groups as soft corals (Coelenterata, Alcyonacea) (Sammarco et al. 1983, Sammarco \& Coll 1988), sponges (Sullivan et al. 1983, Thompson 1985) and sea anemones (Chan et al. 1980, Bak \& Borsboom 1984).

Ichthyotoxic (Coll et al. 1982b, Coll \& Sammarco 1983, unpubl. data) terpenoid toxins (secondary metabolites) in soft corals (Bowden \& Coll 1983) can cause tissue necrosis in neighboring scleractinian and alcyonacean corals, with or without physical contact (Sammarco et al. 1983, 1985, La Barre et al. 1986). The presence of soft coral toxins in seawater surrounding some of these soft corals and their effectiveness on scleractinian competitors has been confirmed in the field and laboratory respectively (Coll et al. 1982a, Coll \& Sammarco 1983). The efficacy of these toxins is highly species-specific (Sammarco et al. 1985).

Competitive interactions such as these are usually assumed to have predictable outcomes. Dominance may vary in degree between interacting pairs of species, but, in a given environment, one species can usually be expected to ultimately dominate the other, except in cases where non-transitive competitive networks are involved (Buss \& Jackson 1979, Karlson \& Jackson 1981, Russ 1982). Environmental factors, physical or biological, may alter the ultimate outcome of such competitive interactions.

Physical environmental factors are known to influence zonation and distribution of coral assemblages on reefs (Bradbury \& Young 1981). In the central region of the Great Barrier Reef, physical variables such as temperature, salinity, turbidity, wave energy, and light penetration vary across the continental shelf (Done 1983, Andrews \& Furnas 1986, Gagan et al. 1987. 1988), which spans $120 \mathrm{~km}$. There is also a welldocumented gradient in biological community types (Ikeda et al. 1980, Done 1982, Revelante et al. 1982, Williams 1982, Dinesen 1983, Drew 1983a, Sammarco 1983a, 1991, Sammarco \& Crenshaw 1984, Klumpp \& McKinnon 1989).

On many mid-shelf reefs, scleractinian corals dominate the benthic fauna, co-occuring with octocorals and other sessile colonial organisms (Done 1982, Dinesen 1983). On inshore platform reefs and the fringing reefs of coastal islands (e.g. Orpheus Island, Queensland, Australia), octocorals can dominate the benthic epifauna (La Barre 1984, Alino 1989). At certain sites on one inshore reef (Pandora Reef in the Great Barrier Reef), octocorals are overgrowing live scleractinian corals to the point of near monopolization, actively excluding this hermatypic component of the reef biota.

Here we will examine through controlled experiments the role of inshore environmental conditions in augmenting competitive advantage in the octocorals. We will present evidence that interspecific interactions between octocorallian and scleractinian corals can be altered and, in fact, reversed by changing the environment in which they occur. We do this by actively relocating competing corals from inshore waters to a mid-continental shelf reef of the central Great Barrier Reef, with appropriate controls.

\section{MATERIALS AND METHODS}

Study sites. All experimentation was performed on 2 reefs in the central region of the Great Barrier Reef. The first was Pandora Reef (Fig. 1), an inshore reef located $15.9 \mathrm{~km}$ from the mainland. It is a coral rubble cay situated in an area characterized by highly variable salinity and seawater temperatures, high sedimentation and turbidity, and low light penetration.

Pandora Reef has a reef flat composed of compacted, loosely lithified, weathered coral rubble. The reef slopes comprise larger skeletons of the dominant scleractinian coral assemblage in the area, i.e. Porites spp., Acropora spp., and Turbinaria spp.

The northern face of Pandora Reef is characterised by a suite of scleractinian and octocoral species. Three encrusting species of octocorals are very common there - Clavularia inflata Schenck var. luzoniana May, Briareum stechei (syn. Solenopodium stechei Kukenthal), and Pachyclavularia violacea (syn. $P$. erecta Roule), along with several scleractinian corals, including Acropora longicyathus Edwards \& Haime (Alino 1989).

Octocorals in this area are actively and rapidly overgrowing the scleractinian corals and outcompeting them for space, to a point approaching the local competitive exclusion of various scleractinians (Fig. 2). In many cases, necrotic effects were observed in the soft coral/scleractinian coral interaction zones. The photographs shown in Fig. 2, of course, depict only static 'snapshots' of the competitive interactions (Connell 1976, Karlson 1980, Sebens 1986a, b). The geomorphology, biotic cover, the 8 yr of observations we have made in this area, and a 6 yr series of survey photographs made by T. Done (1981 to 1987 ; in Alino 1989), however, reveal that the octocorals are indeed en- 
Fig. 1. Central region of the Great Barrier Reef, Australia, depicting the 2 major study sites, Pandora Reef and Britomart Reef Their respective distances from shore are 15.9 and $45.6 \mathrm{~km}$ (distance to study sites)

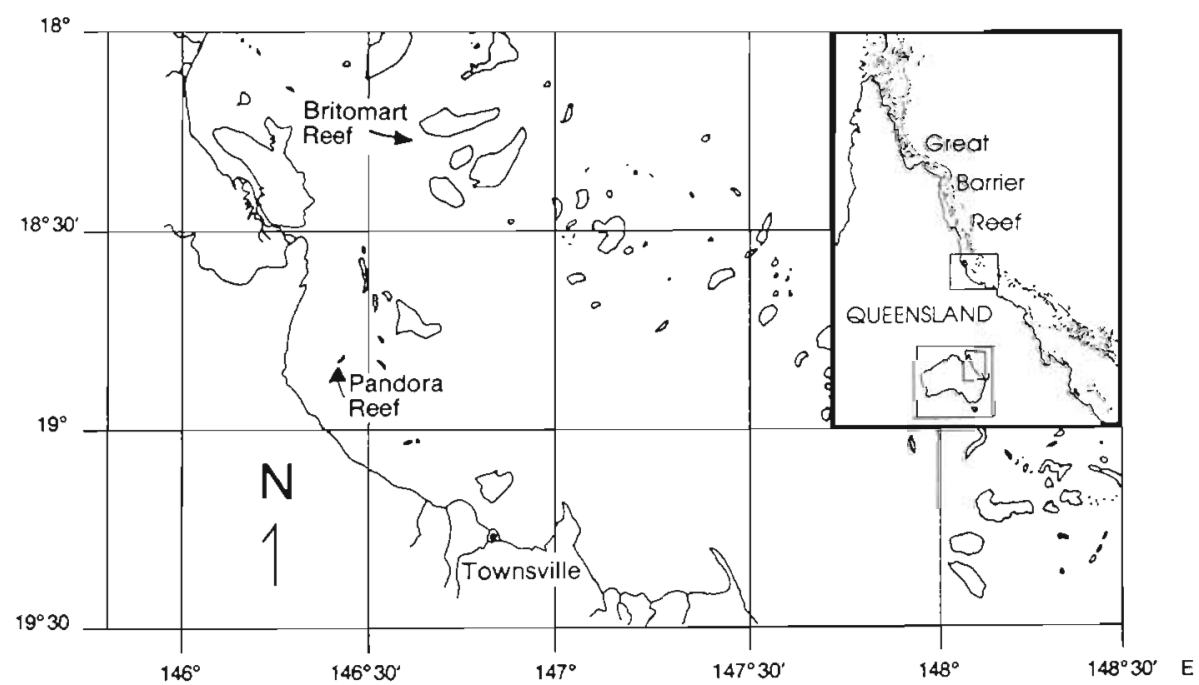

scleractinian corals dominate, and these octocorals are scarce. Britomart Reef is characterized by lower variations in temperature and salinity, lower sedimentation croaching on scleractinian space on a large scale.

This situation was quite different to that observed on Britomart Reef, $45.6 \mathrm{~km}$ from shore (Fig. 1). There,
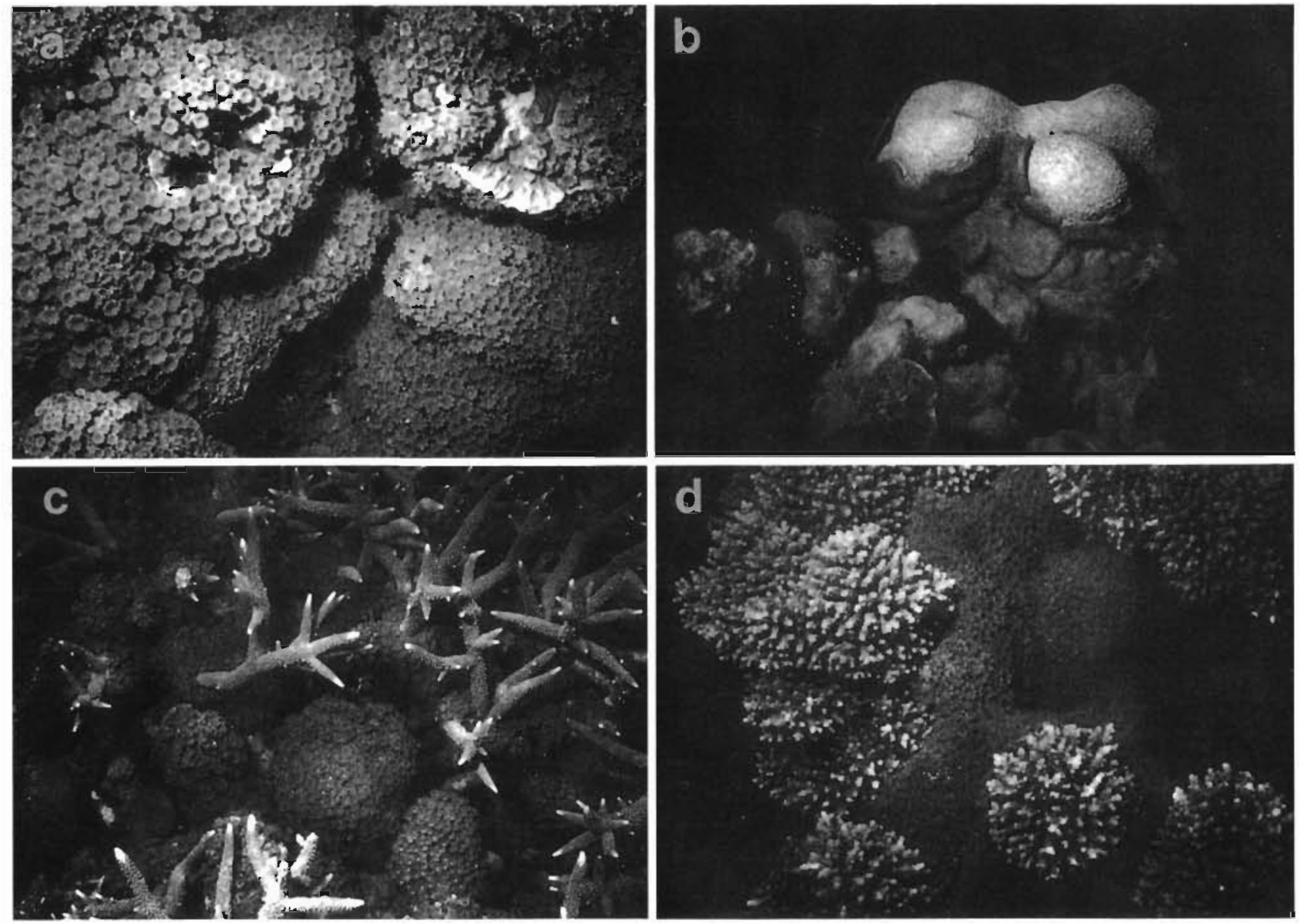

Fig. 2. Examples of octocorals overgrowing living scleractinian corals on Pandora Reef in inshore waters of the Great Barrier Reef. Phenomenon occurring on a massive scale. Note how geomorphology is retained. (a) Clavularia inflata overgrowing Pavona varians. (b) Briareum stechei overgrowing Goniopora sp. (c) C. inflata overgrowing Acropora formosa. (d) C. inflata overgrowing A. longicyathus 
and turbidity, higher light penetration, and a different complement of reef fish (Williams 1982).

Transects. Two $10 \mathrm{~m}$ transects were run perpendicular to shore specifically in the octocoral-dominated study area (northern face of Pandora Reef, 3 to $5 \mathrm{~m}$ depth), following the technique described by McManus \& Wenno (1981). Semi-quantitative observations of the dominant sessile epibenthic organisms were made. Bottom cover was estimated in each transect.

The frequency of interactions with respect to competition for space between species was also recorded. Interactions were judged as a win, stand-off, or in- determinate outcome (simultaneous reciprocal overgrowth, or no interaction). Percent-cover, frequency of occurrence and frequency of interaction amongst species were recorded.

Experimental design. Pairs of alcyonarian octocorals and scleractinian corals from Pandora Reef, actively competing for space, were relocated to Britomart Reef into a large hole behind the reef crest (Hole 1A; see Sammarco 1983b). There, they were protected from wave exposure, much like the site from which they were sampled on Pandora Reef. Competing colonies were thus exposed to a different

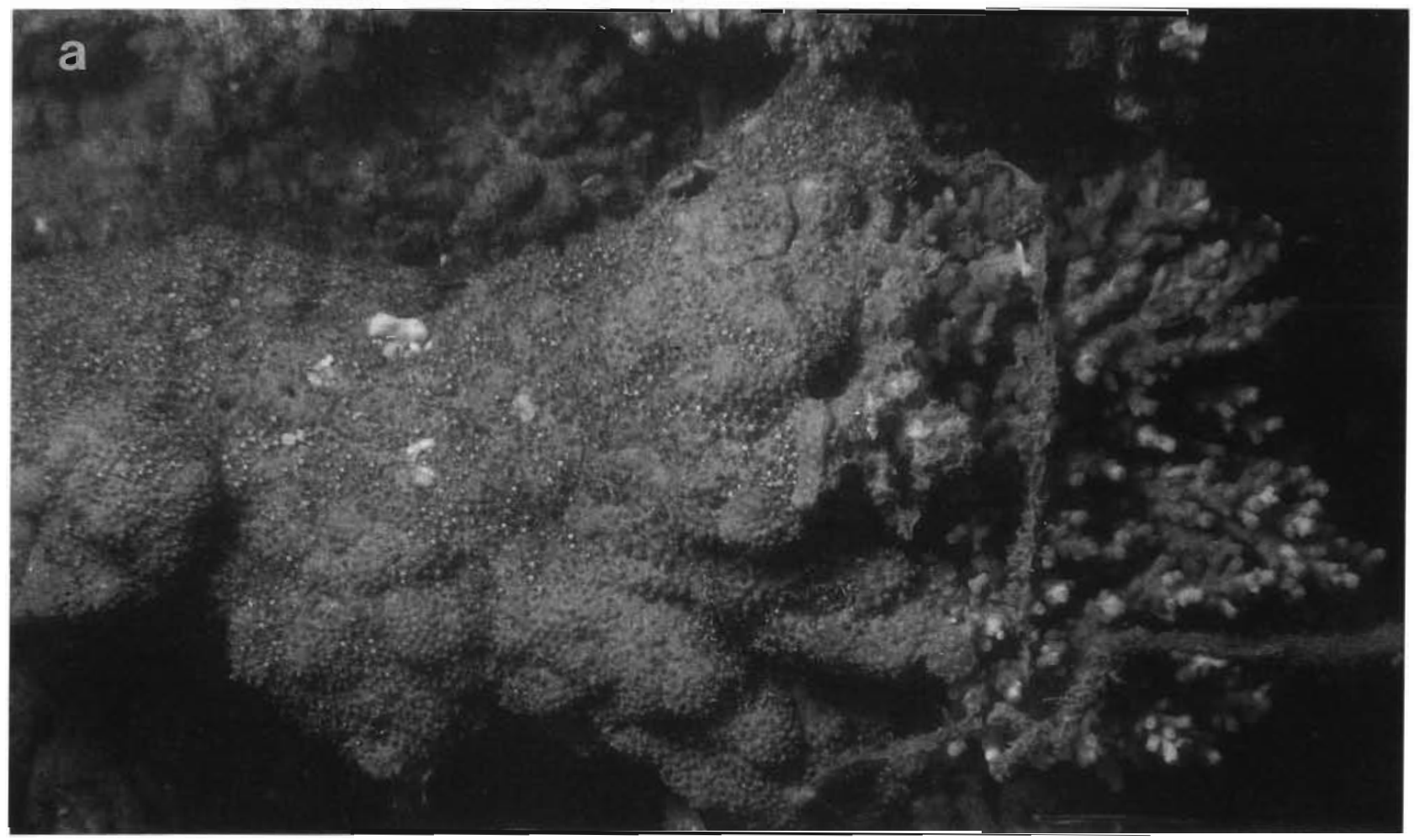

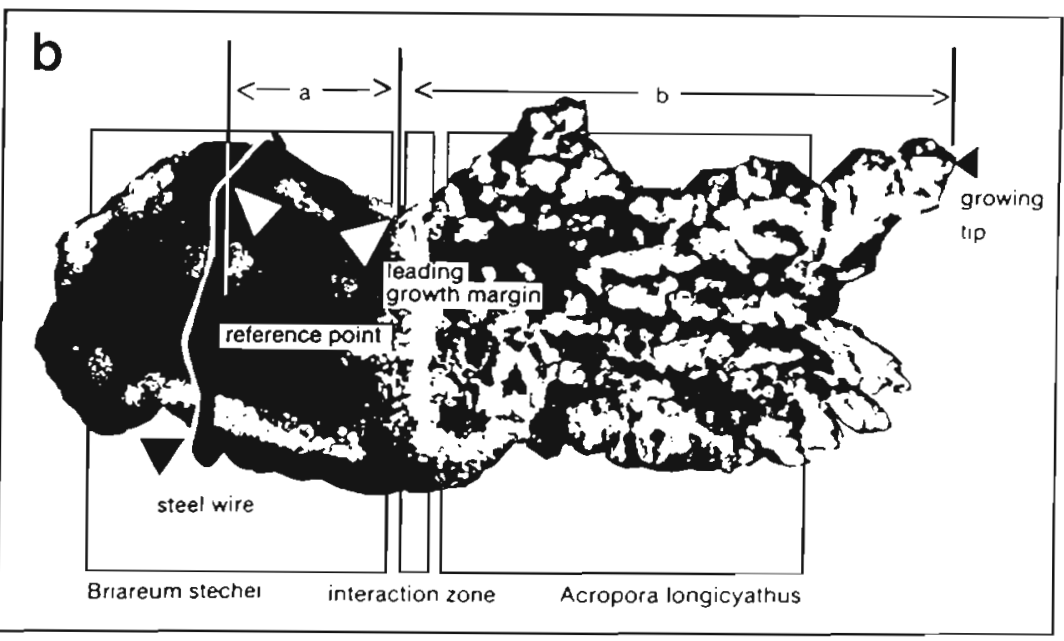

Fig. 3. Acropora Iongicyathus in active competition for space with Briareum stechei, to illustrate means by which relative growth was measured. (a) Photo (b) Diagram. Relative growth $(M)$ in a set of paired competing colonies (i) at a point $(t)$ in time was calculated as

$$
\begin{gathered}
M_{1 i}=\frac{a_{i t}+k_{i}}{a_{i t}+k_{i}+b_{i t}} \\
k_{1}=b_{t=0}=a_{l=0 ;} M_{1, t=0}=0.50
\end{gathered}
$$

where $a_{i t}=$ distance from reference point (steel wire) on paired colony (i) to growing margin of e.g. Briareum at time $(t)_{i} b_{t t}=$ distance from leading growth margin of the octocoral colony (i) to growing tip of Acropora at time $(t) ; k_{i}=$ standardisation constant (in $\mathrm{mm})$, unique to each experimental pair of colonies. (Equation allows for standardisation of $M$ to an initial value of $50 \%$ to facilitate comparison through time) 
set of physical and biological conditions (e.g. increased abundance of predators) to help assess the impact of the environment on the outcome of existing competitive encounters.

The experiment followed a balanced, 3-way, replicated, mixed-model ANOVA design (Sokal \& Rohlf 1981), with appropriate controls. The first fixed factor (1) of the design involved relocation, with 3 treatments: (a) the transplant treatment (referred to as Tl, described above; (b) relocation of corals to Britomart Reef with immediate return to Pandora (referred to as TC transplant controls), to control for handling effects; and (c) non-transplant controls (NT) - i.e. monitoring nonmanipulated corals on Pandora Reef. The second fixed factor (2) represented all possible combinations of the 3 different coral species used in the experiment: (a) pieces of Acropora longicyathus and Briareum steche actively competing for space; (b) A. longicyathus and Clavularia inflata; (c) B. stechei and C. inflata; (d) healthy colonies of $A$. longicyathus alone, to control for growth and survival rates under non-competitive conditions; (e) pieces of $B$. stechei alone; and (f) pieces of $C$. inflata alone. The third factor (random; 3 ) involved replication of the first 2 factors in space via 3 randomly located blocks - A, B, and C. Within each treatment and each block, samples were further replicated 3 times. In certain instances (e.g. growth measurements), several readings (sub-replicates) were taken on each replicate sample.

The experiment was initiated in November 1985 and continued through November 1986. Data were collected in situ at approximately bi-monthly intervals.

Growth of colonies was assessed by measurements made from a reference point marked on the substratum. A piece of PVC-coated or stainless steel wire was tied to the substratum around one of the interacting colonies and the distance to the interaction zone as well as to the tip of the competing colony was measured (Fig. 3). Simple, absolute linear growth was measured in competing colonies. This was converted to relative growth, based upon distance to the steel wire (the reference point), to facilitate comparisons of competitive advantage through time. Measurements were converted to proportional changes in length from the original interaction point. Initial readings (time $t_{0}$ ) were all standardized to $50 \%$, and subsequent readings were compared with that original value (see legend of Fig. 3)

This technique of using relative growth for tracking competitive interactions varies to some degree from those used previously (e.g. Connell 1976, Karlson 1980 , Sebens $1986 \mathrm{a}, \mathrm{b})$. The present technique provides a new and simple technique for deriving an easily interpretable assessment of changes through time. The technique depicts unidirectional or seasonal changes in encroachment patterns between pairs of species particularly well.

In order to ensure that growth rates could be compared in all cases, the pieces of substratum (colony sizes) were also initially analysed for uniformity in size. If the lengths of pieces of substratum from one treatment were significantly larger on the average than those from other treatments, relative growth rates were adjusted (coded; Sokal \& Rohlf 1981), multiplying them by a second constant before making comparisons. (There were few cases where this was necessary, and adjustments were minor.)

Five other types of information were collected on the corals to assess physiological effects and effects of change in environment on competitive interactions, as follows:

Frequency of overgrowth at the micro-scale. Observations of the polyps of one competing species overgrowing the polyps of the other, considered at the micro-scale. These data should not be confused with relative growth rate data or absolute/colony linear extension rate data. The interaction zone (Fig. 3) served as the focus of observation here.

Tissue necrosis. Observations of tissue necrosis in the competing species in the interaction zone, again at the micro-scale.

Whole-colony mortality. Observations of total colony mortality in the competing species.

Bleaching. Observations of bleaching of tissue in the competing species in the interaction zone, at the micro-scale.

Predation. Observations of evidence of predation on the coral colonies (usually fish grazing marks or related colony breakage\}.

All data were analyzed by standard parametric techniques (see Sokal \& Rohlf 1981). Growth data were analyzed by ANOVA, linear regression, and planned (a priori) pairwise comparisons of regression coefficients. Data on bleaching, necrosis, overgrowth, mortality, and predation were analyzed by 2 -way frequency analyses using the G-statistic. Details on results of statistical analyses are presented in the text, in figure legends, and in tables. Only significant changes or differences between treatments will be discussed.

\section{RESULTS}

\section{Distribution, abundance, and interactions of the benthos at study site}

On the reef slope at 3 to $5 \mathrm{~m}$ depth, specifically in the experimental area, the benthos was comprised of ca $56 \%$ octocorals (Table 1), predominantly Clavularia inflata, Briareum stechei, and Pachyclavularia viola- 
Table 1 Percent-cover of epibenthic species in the octocoral dominated study area on Pandora Reef, as determined by two $10 \mathrm{~m}$ line transects

\begin{tabular}{|lccc|}
\hline Species & \multicolumn{3}{c|}{ Transect } \\
& 1 & 2 & Average \\
\hline Clavularia inflata & 23.90 & 29.10 & 26.50 \\
Acropora longicyathus & 22.1 & 10.6 & 16.35 \\
Briareum stechei & 16.4 & 14.3 & 15.35 \\
Pachyclavularia violacea & 16.4 & 14 & 15.2 \\
Turbinaria mesenteriana & 0 & 15.3 & 7.65 \\
Acropora intermedia & 14.5 & 0 & 7.25 \\
Substratum & 9.7 & 3.8 & 6.75 \\
Protopalythoa sp. & 0 & 8.1 & 4.05 \\
Acropora spp. & 0 & 4.9 & 2.45 \\
\hline
\end{tabular}

cea. Of the benthos, $34 \%$ was accounted for by scleractinian corals, of which $16 \%$ was Acropora longicyathus. The remainder was accounted for predominantly by other scleractinian corals $(17 \%)$, substratum $(7 \%)$, and Protopalythoa sp. (zoanthid, $4 \%$ ) (Table 1).

Scleractinian/octocoral associations accounted for $45 \%$ of all associations observed in the study site (Table 2). Octocoral/octocoral associations accounted for $28 \%$ of all associations there. Interactions between Protopalythoa and scleractinian corals, and Protopalythoa and octocorals accounted for ca $7 \%$ and $2 \%$ of the pairings, respectively, in the experimental area. Associations between Clavularia inflata, Briareum stechei, and Acropora longicyathus in any combination comprised ca $33 \%$ of the total associations. Pachyclavularia violacea was also found to account for a substantial proportion of interactions in the study area.

\section{Relative growth in actively competing species (comparative colony extension)}

\section{Acropora - Clavularia interactions}

This set of data compares growth rates or colony extension rates of the 2 competing species in question. The data are standardised, thus yielding growth rates relative to each other.

Under natural (NT) conditions, Clavularia inflata was significantly superior to Acropora longicyathus in terms of growth (Fig. 4a; Table 3). When transplanted to the mid-shelf $(\mathrm{T})$, this competitive advantage was reversed, and negative growth was observed in $C$. inflata (Fig. 4c; Table 3). No significant competitive advantage was exhibited by either species in transplant control colonies (TC; Fig. 4b; Table 3). This equivocal response noted in the transplant control colonies (TC) was significantly different from that in the transplant

Table 2. Associations between pairs of sessile epibenthic species on Pandora Reef and their frequency in percent. Data combined for 2 transects specifically in the octocoral-dominated area used for this study ( 3 to $5 \mathrm{~m}$ depth)

\begin{tabular}{|c|c|c|c|c|}
\hline \multicolumn{2}{|c|}{ Species associations } & \multicolumn{3}{|c|}{ Transect } \\
\hline A & $\mathrm{B}$ & 1 & 2 & Average \\
\hline Clavularia inflata & Acropora longicyathus & 19.20 & 19.10 & 19.15 \\
\hline C. inflata & Pachyclavularia violacea & 4.1 & 17.5 & 10.8 \\
\hline A. longicyathus & P. violacea & 8.2 & 11.1 & 9.65 \\
\hline Briareum stechei & C. inflata & 15.1 & 3.2 & 9.15 \\
\hline B. stechei & $P$ violacea & 12.3 & 4.8 & 8.55 \\
\hline B. stechei & A. longicyathus & 6.9 & 3.2 & 5.05 \\
\hline Acropora intermedia & Substratum & 9.6 & 0 & 4.8 \\
\hline C. inflata & Substratum, algae & 6.9 & 1.6 & 4.25 \\
\hline C. inflata & Acropora spp. & 0 & 7.9 & 3.95 \\
\hline A. longicyathus & Protopalythoa sp. & 0 & 7.9 & 3.95 \\
\hline B. stechei & Substratum & 5.5 & 1.6 & 3.55 \\
\hline Protopalythoa sp. & Turbinaria mesenterina & 0 & 6.4 & 3.2 \\
\hline C. inflata & T. mesenterina & 0 & 4.8 & 2.4 \\
\hline B. stechei & A. intermedia & 5.5 & 0 & 2.25 \\
\hline P. violacea & Substratum & 2.7 & 0 & 1.35 \\
\hline Protopalythoa sp. & Algae & 0 & 1.6 & 0.8 \\
\hline Turbinaria ornata & Substratum & 0 & 1.6 & 0.8 \\
\hline T. mesenterina & Substratum & 0 & 1.6 & 0.8 \\
\hline T. mesenterina & P. violacea & 0 & 1.6 & 0.8 \\
\hline B. stechei & T. mesenterina & 0 & 1.6 & 0.8 \\
\hline Protopalythoa sp. & P. violacea & 0 & 1.6 & 0.8 \\
\hline Protopalythoa sp. & B. stechei & 0 & 1.6 & 0.8 \\
\hline A. longicyathus & Substratum & 1.4 & 0 & 0.7 \\
\hline A. intermedia & P. violacea & 1.4 & 0 & 0.7 \\
\hline A. intermedia & C. inflata & 1.4 & 0 & 0.7 \\
\hline
\end{tabular}




\section{RELATIVE GROWTH IN}

Acropora - Clavularia

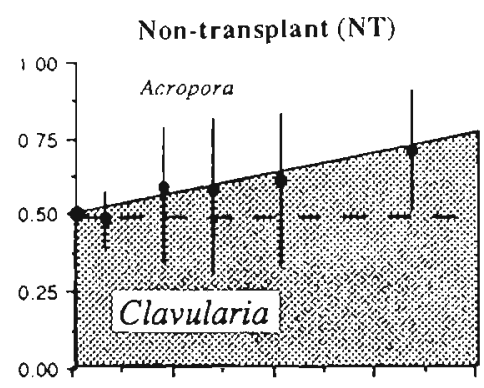

a

ש
Acropora-Briareum

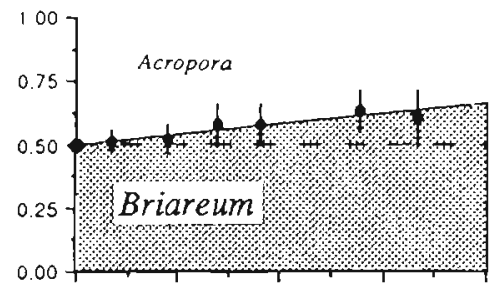

d

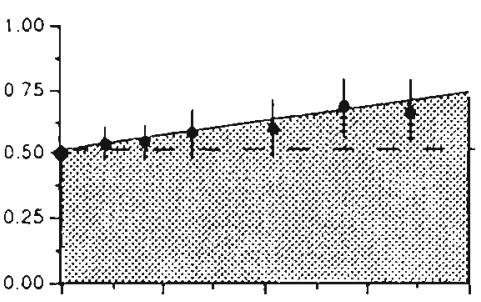

e

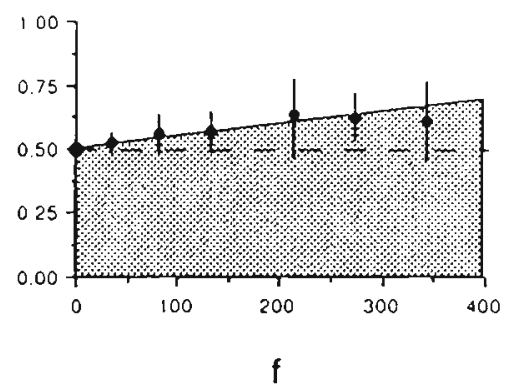

Briareum-Clavularia

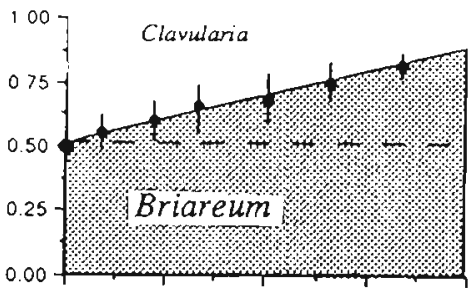

g

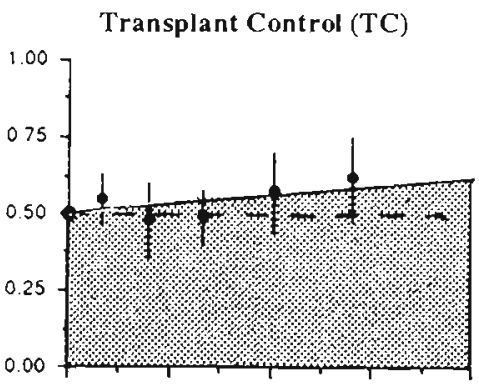

b

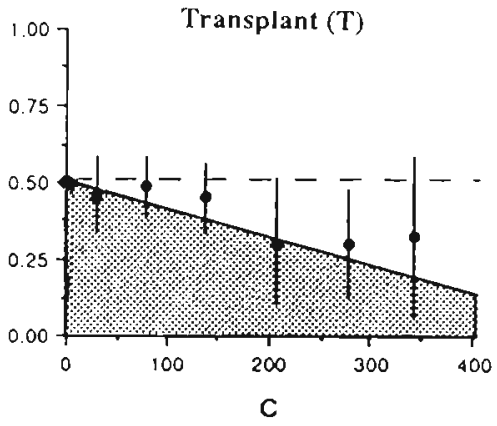

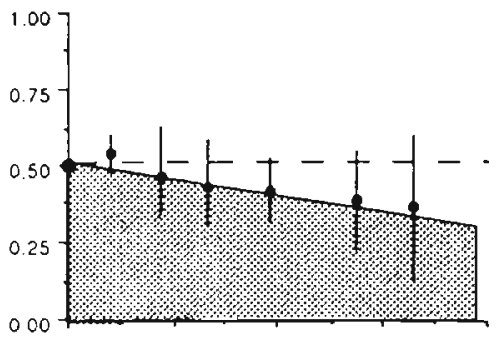

h

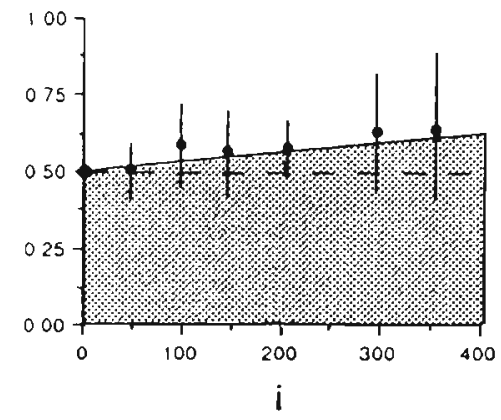

Time (days)

Fig. 4. Relative growth through time of Clavularia inflata, Briareum stechei, and Acropora longicyathus, paired respectively, while in competition for space. Data presented in proportions and standardised to an initial value of $50 \%$ (see Fig. 3). Mean and $95 \%$ confidence intervals shown. See Table 3 for statistical details on regression analyses. Orientation of line indicates relative encroachment of one set of colonies on another; e.g. positive slope denotes encroachment of species in lower half of graph onto species in upper half. Three experimental conditions shown: (a) Acropora and Clavularia paired under natural, non-transplant (NT) conditions on Pandora Reef, undisturbed. Significant encroachment by Clavularia. (b) Acropora and Clavularia paired under transplant control (TC) conditions on Pandora Reef, after having been transported to Britomart Reef on the mid-shelf and returned to their original habitat. No significant changes in relative growth through time; (see text for explanation). (c) Competing paired colonies of Acropora and Clavularia transplanted (T) to the mid-shelf. Significant recession in Clavularia through time. (d) Relative growth through time of Briareum stechei paired with Acropora longicyathus while in competition for space under natural (non-transplant; NT) conditions. (e) Under transplant control (TC) conditions. (f) Under conditions of transplant (T) to the mid-shelf. Significant encroachment by Briareum through time in all cases. (g) Relative growth through time of Briareum stechei paired with Clavularia inflata under natural (non-transplant; NT) conditions; significant encroachment by Briareum on Clavularia through time. (h) Under transplant control (TC) conditions; no significant change through time (see text for explanation). (i) Under conditions of transplant (T) to the mid-shelf; no significant change through time 
Table 3. Results of linear regression analyses performed on growth related data in all treatments. Regression equation, level of significance of regression coefficient, and sample size presented by treatment. Treatments nested within speciespairings and, in the case of controls, within species. $X=$ time in days. $Y=$ relative growth in percent for all cases except Acropora longicyathus; there, $Y=$ growth in $\mathrm{mm} \cdot \cdot \mathrm{p}<0.05$; $\cdots p<0.01 ; \cdots p<0.001 ;$ ns: not significant

\begin{tabular}{|c|c|c|c|}
\hline Treatment & Regression equation & $\begin{array}{c}\text { Significance } \\
\text { level }\end{array}$ & $\mathrm{n}$ \\
\hline \multicolumn{4}{|c|}{ Acropora longicyathus - Clavularia inflata } \\
\hline NT & $Y=0.0006 X+(0.4801)$ & $\cdots$ & 43 \\
\hline $\mathrm{TC}$ & $Y=0.0002 X+(0.4678)$ & ns & 47 \\
\hline $\mathrm{T}$ & $Y=-0.0009 X+(0.5146)$ & $\cdots$ & 58 \\
\hline \multicolumn{4}{|c|}{ Acropora longicyathus - Briareum stechei } \\
\hline NT & $Y=0.0004 X+(0.5051)$ & $\cdots$ & 52 \\
\hline $\mathrm{TC}$ & $Y=0.0005 X+(0.4718)$ & $\cdots$ & 74 \\
\hline $\mathrm{T}$ & $Y=0.0046 X+(0.5004)$ & $\cdots$ & 58 \\
\hline \multicolumn{4}{|c|}{ Briareum stechei - Clavularia inflata } \\
\hline NT & $Y=0.0009 X+(0.5195)$ & $\cdots$ & 53 \\
\hline $\mathrm{TC}$ & $Y=-0.0005 X+(0.5065)$ & ns & 49 \\
\hline $\mathrm{T}$ & $Y=0.0003 X+(0.4549)$ & ns & 59 \\
\hline \multicolumn{4}{|c|}{ Acropora longicyathus (solo) } \\
\hline NT & $Y=0.0984 X+(-0.4955)$ & $\cdots$ & 45 \\
\hline TC & $Y=0.0984 X+(-1.8225)$ & $\cdots$ & 65 \\
\hline $\mathrm{T}$ & $Y=-0.0002 X+(3.1014)$ & ns & 82 \\
\hline \multicolumn{4}{|c|}{ Clavularia inflata (solo) } \\
\hline NT & $Y=0.0006 X+(0.3615)$ & $\cdots$ & 47 \\
\hline TC & $Y=0.0006 X+(0.3854)$ & - & 38 \\
\hline$\Upsilon$ & $Y=-0.0002 X+(0.3358)$ & ns & 52 \\
\hline \multicolumn{4}{|c|}{ Briareum stechei (solo) } \\
\hline NT & $Y=0.0003 X+(0.3734)$ & .. & 57 \\
\hline $\mathrm{TC}$ & $Y=0.0006 X+(0.3253)$ & - & 49 \\
\hline $\mathrm{T}$ & $Y=0.0011 X+(0.3414)$ & $\cdots$ & 57 \\
\hline
\end{tabular}

treatment ( $\mathrm{T}$ ) but not significantly different from that observed in the colonies occurring under natural (NT) conditions $(p>0.05$, pairwise comparison between regression coefficients, $F$-test).

\section{Acropora - Briareum interactions}

Briareum stechei was significantly competitively superior to Acropora longicyathus under natural conditions (NT) (Fig. 4d; Table 3). This degree of superiority was retained in both transplant ( $T$; Fig. 4f; Table 3 ) and transplant control (TC) colonies (Fig. 4e; Table 3). There was no significant difference in relative growth relationships between Acropora - Clavularia and Acropora - Briareum pairings on Pandora Reef ( $p>0.05$, pairwise comparisons of regression coefficients); that is, both octocorals exhibited equivalent competitive advantage over Acropora there.

\section{Briareum - Clavularia interactions}

Briareum stechei was significantly competitively superior to Clavularia inflata under natural conditions (NT; Fig. 4g; Table 3). This competitive advantage decreased to 'stand-off' levels (no win; not significantly different from zero) when interacting colonies were transplanted $(\mathrm{T})$ to the mid-shelf (Fig. 4i; Table 3). Briareum exhibited a further significant loss of competitive advantage with respect to relative growth in the transplant controls (TC).

The degree of competitive superionty of Briareum over Clavularia and over Acropora under natural (NT) conditions was approximately equal; i.e. their relative growth relationships were not significantly different (Fig. 4d, g; p > 0.05, comparison of regression coefficients). Briareum also retained its competitive advantage over these species to the same degree when transplanted ( $T$; Fig. 4f, i; $p>0.05$ ). Both Briareum and Clavularia exhibited the same general degree of competitive superiority over Acropora under natural (NT) conditions (Fig. 4a, $d_{i} p>0.05$, comparison of regression coefficients).

\section{Growth response of non-interacting colonies}

This set of data describes the absolute growth rates of the coral colonies in question when not involved in competition for space with the other species. Data have once again been standardized to facilitate comparison with data from the above treatments.

Acropora longicyathus exhibited an average linear growth rate of $35.4 \mathrm{~mm} \mathrm{yr}^{-1}$ under natural conditions on Pandora Reef (Fig. 5a; Table 3). When transplanted to the mid-shelf $(T)$, this growth rate dropped significantly (Fig. $5 \mathrm{c} ; \mathrm{p}<0.05$, comparison of regression coefficients). Transplant control colonies (TC) exhibited normal growth patterns (Fig. 5b), not significantly different from those under natural (NT) conditions $(p>0.05)$.

Clavularia inflata overgrew bare reef substratum at a linear rate of $76.6 \mathrm{~mm} \mathrm{yr}^{-1}$. Its growth was highly variable and exhibited some seasonality, with a peak rate occurring in the late summer (Fig. 5a). Transplant colonies ( $\mathrm{T}$ ) exhibited no growth (Table 3), with a trend towards negative colony growth (Fig. 5f). Transplant controls (TC) exhibited the same growth patterns as those under natural (NT) conditions (Fig. $5 e_{i}$ Table 3,p $>0.05$, comparison of regression coefficients).

Briareum stechei expanded at a linear rate of 43.8 $\mathrm{mm} \mathrm{yr}^{-1}$ under natural (NT) conditions (Fig 5g; Table 3). Growth rate increased significantly in transplant $(\mathrm{T}$ ) colonies (Fig. 5i; $\mathrm{p}<0.05$, comparison of 
Growth of

Acropora longicyathus

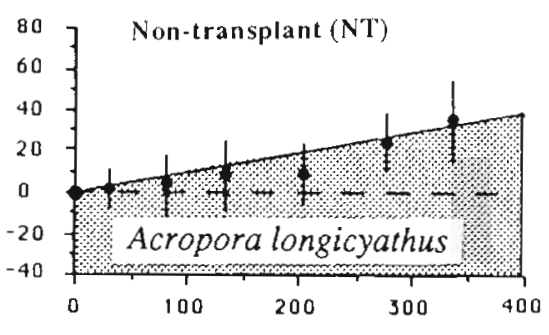

a
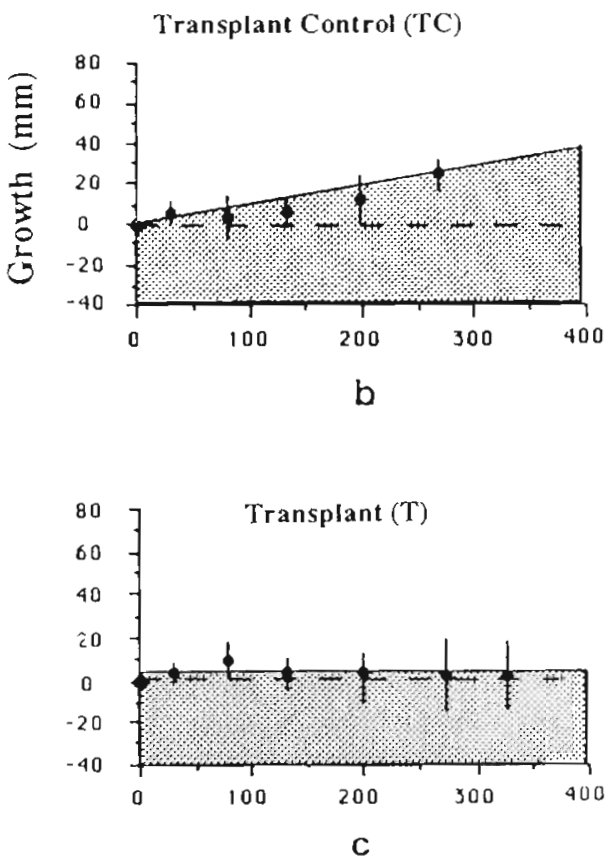

Relative growth in

Clavularia inflata

Briareum stechei

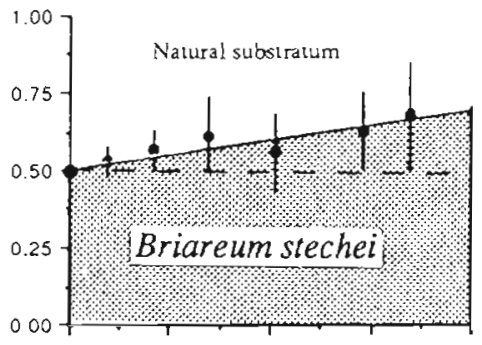

9

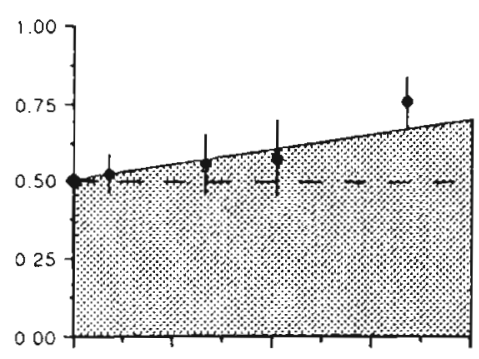

h

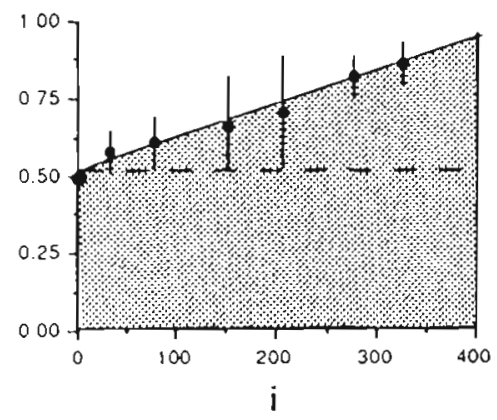

Time (days)

Fig. 5. Acropora longicyathus. Growth through time (mm) under (a) natural (non-transplant; NT), (b) transplant control (TC), and (c) transplant (T) conditions. Significant growth under natural (NT) and transplant control (TC) conditions, but not under conditions of transplant to the mid-shelf. (d) Relatıve growth through time in Clavularia inflata measured as a proportion of distance to edge of unoccupied substratum. Data presented in proportions. Mean and $95 \%$ confidence intervals shown under natural (nontransplant, NT), (e) transplant control (TC), and (f) transplant (T) conditions. Significant growth under natural (NT) and transplant control (TC) conditions but not under transplant (T) conditions. (g) Relative growth through time in Briareum stechei measured as a proportion of distance to edge of unoccupied substratum under natural (non-transplant, NT), (h) transplant control (TC), and (i) transplant (T) conditions. Significant positive growth under all 3 treatments. See Table 3 for statistical details

regression coefficients). Transplant control colonies (TC) grew at a rate intermediate to those growing under natural (NT) and treatment (T) conditions, but was not significantly different from either group (Fig. 5h; $p>0.05$ ).

\section{Other effects on the corals}

These multi-faceted data will be presented by species pairings, in order to provide an overall view of changes in the competitive relationships between 
them in response to the treatments imposed. Polyp overgrowth, tissue necrosis, and bleaching will be considered at the micro-scale in the interaction zone. Whole colony mortality data and evidence of predation will also be presented here. All statistical probabilities cited in this section refer to results of row by column frequency analyses using the $G$-statistic (Sokal \& Rohlf 1981).

\section{Clavularia - Acropora interactions}

The frequency of Clavularia polyps actively overgrowing Acropora polyps (at the micro-scale) under natural (NT) conditions was high (Fig. 6; p < 0.001). When these colonies were transplanted to the midshelf $(\mathrm{T})$, this high frequency dropped to nil levels. Transplant control colonies (TC) exhibited intermediate frequencies of overgrowth, significantly different from both of the other treatments. Acropora longicyathus was never observed to overgrow Clavularia inflata (Fig. 6 $b_{i} p>0.05$ ).

Under natural conditions, Clavularia induced low levels of tissue necrosis in the interaction zone in Acropora (NT; Fig. 6c). When colonies were transplanted (T) to the mid-shelf, however, this frequency increased to $100 \%(\mathrm{p}<0.001)$. Transplant controls again exhibited intermediate effects. Acropora was never observed to induce tissue necrosis in Clavularia (Fig. $6 \mathrm{~d}$; $\mathrm{p}>$ $0.05)$.

Acropora suffered very low levels of whole colony mortality under natural conditions on Pandora Reef (NT) in the presence of Clavularia. This increased significantly to almost $60 \%$ in colonies transplanted (T) to the mid-shelf (Fig. 6e; $\mathrm{p}<0.001$ ). No whole colony mortality was observed in transplant controls. No significant whole colony mortality was observed in Clavularia (paired with Acropora) under any treatments (Fig. 6f $\mathrm{f}_{i} \mathrm{p}>0.05$ ). The overall size of Clavularia colonies, however, was observed to greatly diminish through time, usually with a small proportion of the original colony remaining at the end of the experiment. That is, partial colony mortality was the rule in Clavularia colonies transplanted to the mid-shelf.

Acropora paired with Clavularia under natural conditions (NT) often exhibited tissue bleaching in the interaction zone (Fig. 6g). This effect was significantly reduced when paired colonies were transplanted to the mid-shelf in transplant colonies $(T ; p<0.01)$. Transplant controls (TC) exhibited intermediate levels of bleaching. Bleaching was never observed in Clavularia paired with Acropora (Fig. 6h; $\mathrm{p}>0.05$ ).

There was no evidence of predation on either Acropora or Clavularia (when paired) under natural condi-
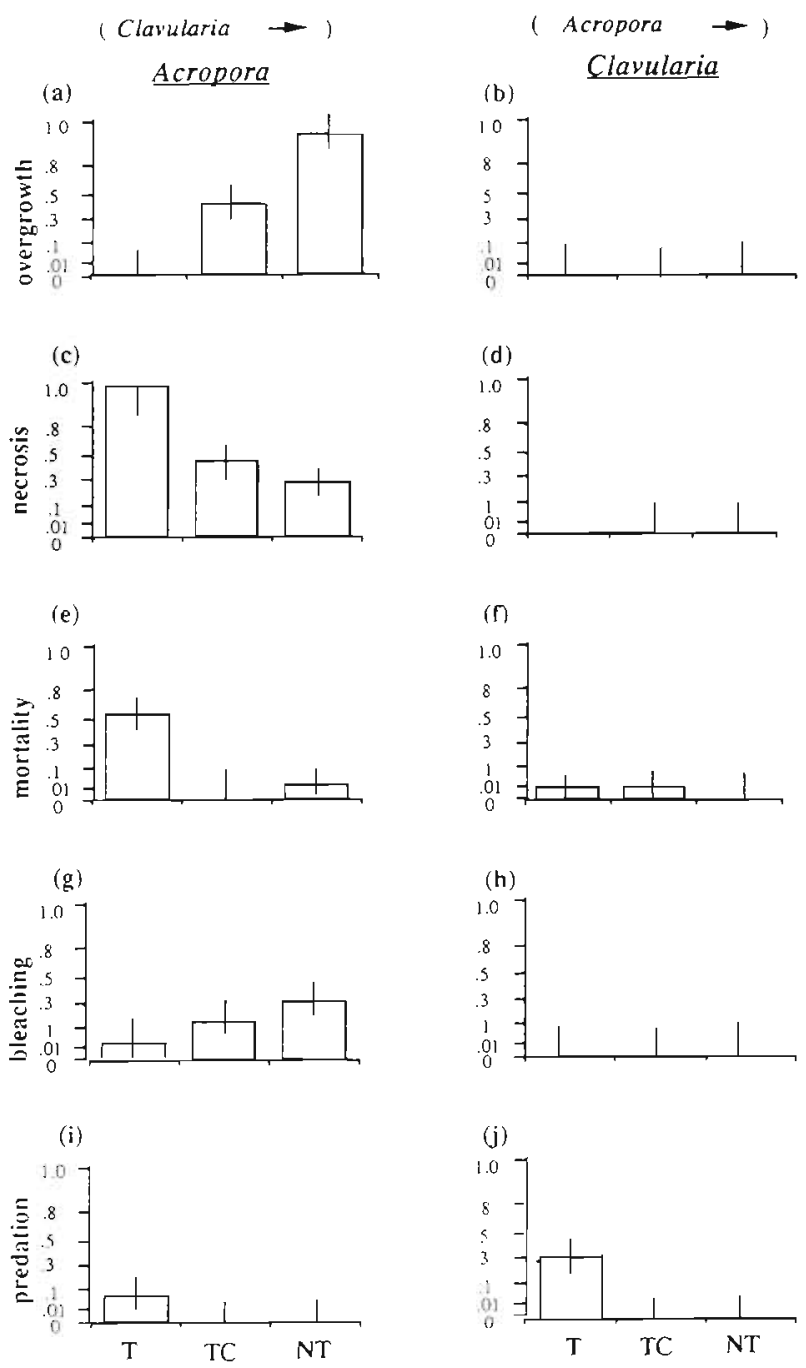

Fig. 6. Clavularia inflata and Acropora longicyathus. Frequency of various responses in colonies actively competing for space. These are responses to the presence of a competitor and predators under different experimental conditions. Data presented as proportion with $95 \%$ confidence intervals. Data transformed by arcsine for purposes of normalization (see Sokal \& Rohlf 1981). Responses to competitor categorized as overgrowth, tissue necrosis, and bleaching at the micro-scale. Evidence of tissue or skeleton damage considered indicator of predation. Effects observed under transplant (T), transplant control (TC), and natural (nontransplant, NT) conditions. See legend of Fig. 4 for details on treatments. Effect of species $a$ on species $b$ denoted by $(a \rightarrow) b$

tions (NT) and in the transplant controls (TC). Such effects were only observed in the colonies transplanted to the mid-shelf ( $T$; Fig. 6i, j); there, Acropora experienced a higher frequency of predation than Clavularia $(\mathrm{p}<0.001)$. 


\section{Briareum - Acropora interactions}

Briareum colonies were observed to overgrow Acropora (at the micro-scale) in $100 \%$ of the cases occurring under natural (NT) conditions (Fig. 7a). The reverse situation was never observed (Fig. 7b). When these pairs were transplanted (T) to the mid-shelf, this frequency dropped significantly $(\mathrm{p}<0.01)$. Still, transplanted Acropora polyps were not observed to over-
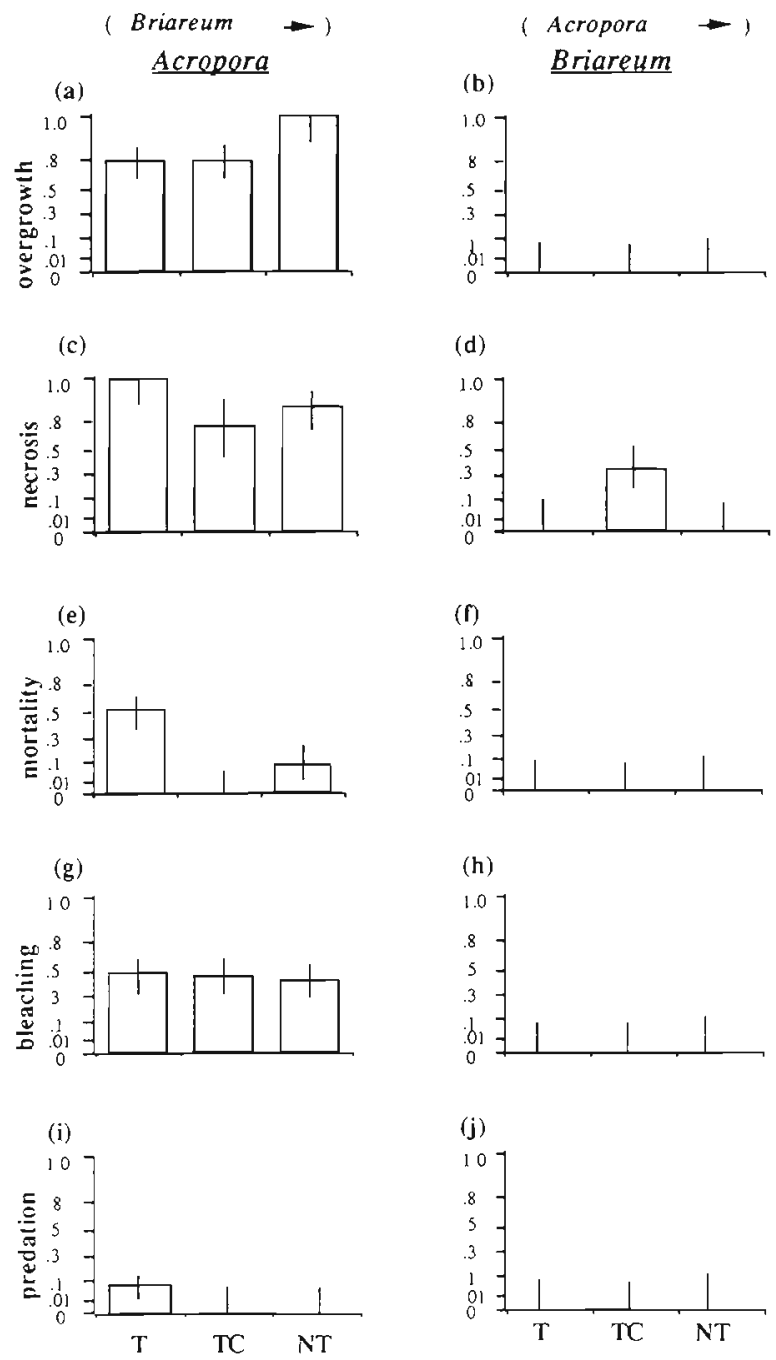

Fig. 7. Briareum stechei and Acropora longicyathus. Frequency of various responses in colonies actively competing for space. Responses to the presence of a competitor and predators under different experimental conditions. Data presented as proportion with $95 \%$ confidence intervals. Data transformed by arcsine for purposes of normalization (see Sokal \& Rohlf 1981). Effects observed under transplant (T), transplant control (TC), and natural (non-transplant, NT) conditions. See legend of Fig. 4 for details on treatments.

Effect of species $a$ on species $b$ denoted by $(a \rightarrow) b$ grow the Briareum colony. Transplant control colonies (TC) exhibited the same decrease in overgrowth frequency as transplants ( $p>0.05$ ).

Under natural conditions, Briareum induced a relatively high level of tissue necrosis in Acropora (NT) in the interaction zone. When paired colonies were transplanted to the mid-shelf, this increased to $100 \%$ (T; Fig. $\left.7 c_{;} p<0.05\right)$. Acropora was not observed to induce any tissue necrosis in Briareum under natural conditions or when transplanted to the mid-shelf (Fig. 7d). Briareum did, however, exhibit tissue necrosis in transplant controls (TC), apparently from storm damage $(\mathrm{p}<0.001)$.

Whole colony mortality in Acropora (paired with Briareum) under natural conditions was low inshore (NT). It increased significantly to $>50 \%$ when paired colonies were transplanted to the mid-shelf ( $\mathrm{T}$; Fig. 7e; $p<0.001)$. No transplanted Acropora colonies survived in the longer term, and colonies were replaced regularly throughout the experiment. Mortality rates shown for transplanted colonies should therefore be considered conservative. Transplant control colonies (TC) exhibited no mortality. Briareum (paired with Acropora) suffered no whole colony mortality (Fig. $7 \mathrm{f}$; $\mathrm{p}>0.05)$.

Briareum induced bleaching in Acropora in the interaction zone equitably in all treatments (Fig. $7 \mathrm{~g}$; $\mathrm{p}>0.05$ ) at levels of $\leq 50 \%$. Acropora was not observed to induce any bleaching in Briareum (Fig. $7 \mathrm{~h}$; $\mathrm{p}>0.05$ )

The Acropora portion of Acropora/Briareum pairings exhibited no significant evidence of predation under natural (NT), transplant control (TC); or transplant (T) conditions ( $\mathrm{p}>0.05)$, although some evidence was noted in the transplant treatment ( $T_{i}$ Fig. 7i). Briareum exhibited no physical signs of predation in any of the treatments (Fig. 7j; p > 0.05). Chaetodon melannotus and Euxiphipops sextriatus (Pisces) were often observed actively preying upon Briareum which had been transplanted to the mid-shelf; the former fish was also observed preying upon Acropora longicyathus. Colony appearance apparently does not reveal this; thus, our data in this area may be considered conservative.

\section{Briareum - Clavularia interactions}

Under natural conditions (NT), Briareum easily overgrew Clavularia at the micro-scale (Fig. 8a). The interaction became more intense when paired colonies were transplanted to the mid-shelf, with overgrowth frequencies increasing to $100 \%(\mathrm{p}<0.001)$. Frequency of overgrowth was lower in transplant controls (TC). Clavularia was not observed to overgrow Briareum 

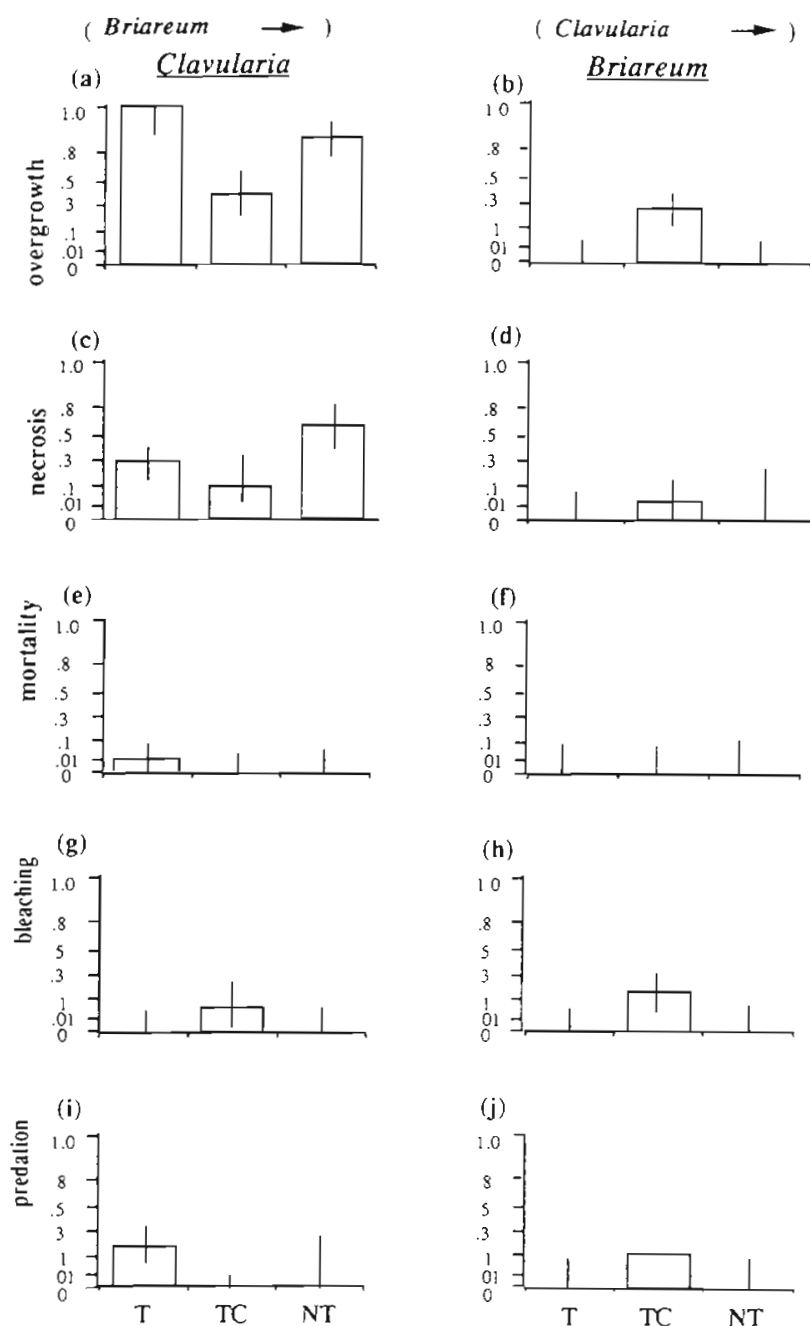

Fig. 8. Briareum stechei and Clavularia inflata. Frequency of various responses in colonies actively competing for space. Responses to the presence of a competitor and predators under different experimental conditions. Data presented as proportion with $95 \%$ confidence intervals. Data transformed by arcsine for purposes of normalization (see Sokal \& Rohlf 1981). Effects observed under transplant (T), transplant control (TC), and natural (non-transplant, NT) conditions. See legends of Fig. 4 for details on treatments. Effect of species $a$ on species $b$ denoted by

$$
(a \rightarrow b
$$

under natural conditions or when pairs were transplanted to the mid-shelf (Fig. 8b). Overgrowth was observed in the transplant controls (TC).

Briareum induced high levels $(67 \%)$ of tissue necrosis in Clavularia under natural conditions (NT; Fig. 8c). This effect decreased significantly when pairs were transplanted to the mid-shelf $(T, p<0.01)$. The decrease was even more pronounced in transplant con- trols (Fig. 8c). Clavularia did not induce any significant tissue necrosis in Briareum under natural or transplant conditions (Fig. 8d; $\mathrm{p}>0.05$ ).

Neither Clavularia nor Briareum (when paired) suffered any significant whole colony mortality in this experiment (Fig. 8e, $\mathrm{f}_{i} \mathrm{p}>0.05$ ). Clavularia did, however, suffer a high degree of partial-colony mortality. Clavularia did not exhibit any significant signs of tissue bleaching (Fig. 8g; p > 0.05). Briareum exhibited bleaching effects in transplant controls (Fig. 8h, $\mathrm{p}<0.001$ )

Clavularia (paired with Briareum) showed no signs of predation under natural conditions inshore. The frequency of observations increased significantly to ca $20 \%$, however, when transplanted to the mid-shelf (Fig. 8i; $p<0.01$ ). Briareum (paired with Clavularia) exhibited no evidence of predation either under natural conditions or when transplanted to the mid-shelf (Fig. 8j). Transplant controls (TC), however, exhibited a significantly higher frequency of apparent predation $(\mathrm{p}<0.01)$.

\section{Acropora controls}

Solo Acropora colonies exhibited no measurable whole colony mortality under natural conditions during the term of the experiment (Fig. 9a). This level increased dramatically to $55 \%$ when colonies were transplanted to the mid-shelf $(p<0.001)$. Acropora transplant controls exhibited no mortality. Acropora exhibited no bleaching under natural conditions inshore, but this increased to $28 \%$ under transplant conditions (Fig. 9b; $p<0.05$ ). Transplant controls exhibited levels of bleaching similar to transplant colonies $(p<0.05)$.

Acropora occurring under natural conditions showed no signs of predation. This increased to $50 \%$ when transplanted to the mid-shelf (Fig. 9c; p < 0.001). Transplant controls exhibited no evidence of predation.

\section{Clavularia controls}

Solo Clavularia exhibited no whole colony mortality under natural conditions inshore, nor did transplant controls of this species (Fig. 9d). Colonies transplanted to the mid-shelf suffered a significantly higher level of mortality $(13 \% ; \mathrm{p}<0.001)$. In no case did Clavularia exhibit signs of tissue bleaching (Fig. $9 \mathrm{e}_{i} \mathrm{p}>0.05$ ).

Clavularia did not exhibit signs of predation under natural conditions inshore (or in transplant controls), but predation frequency increased significantly to $40 \%$ when colonies were transplanted to the mid-shelf (Fig. 9f; $p<0.001$ ). 
Acropora longicyathus

(a)

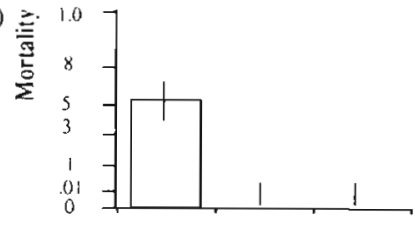

Clavularia inflata

(d)

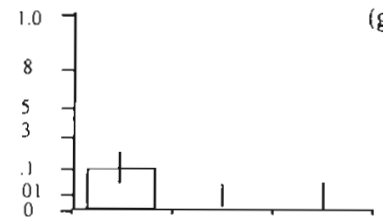

Briareum stechei

g)

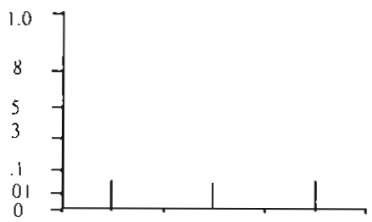

(b)

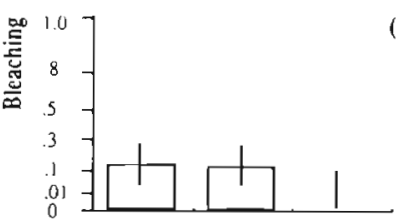

(c)

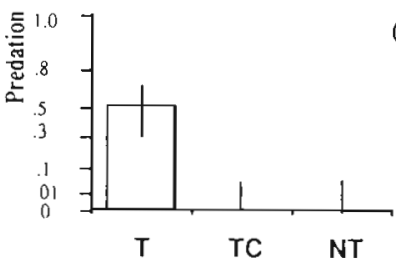

(e)

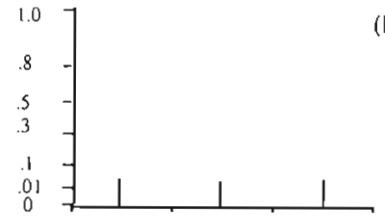

(f)

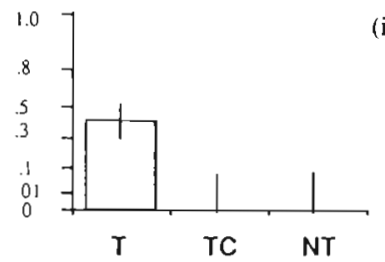

(i) (h)
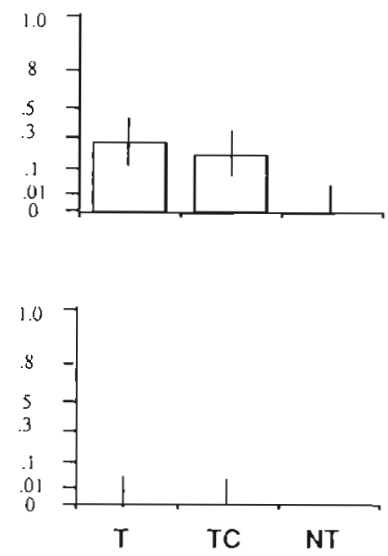

Fig. 9. Acropora longicyathus (a to c), Clavularia inflata (d to f), and Briareum stechei (g to i). Frequency of various responses in solo colonies under different experimental conditions. Frequency of whole colony mortality and bleaching quantified as well as evidence of predation. Data presented as proportion with $95 \%$ confidence intervals. Data transformed by arcsine for purposes of normalization (see Sokal \& Rohlf 1981). Effects observed under transplant (T), transplant control (TC), and natural (nontransplant, NT) conditions. See legend of Fig. 4 for details on treatments

\section{Briareum controls}

No solo Briareum exhibited whole colony mortality or evidence of predation (Fig. 9g, i). They also exhibited no tissue bleaching under natural conditions inshore. Evidence of bleaching significantly increased to ca $28 \%$ when colonies were transplanted to the mid-shelf ( $\mathrm{T}$; Fig. 9h; $\mathrm{p}<0.001$ ); similar levels were observed in transplant controls.

\section{DISCUSSION}

There is little doubt that Clavularia inflata is superior to the scleractinian coral Acropora longicyathus in competition for space under natural conditions in inshore waters of the central Great Barrier Reef. This was evident through relative growth rates when involved in competition as well as frequency of observation of overgrowth, tissue necrosis, whole colony mortality rates, and bleaching. Indeed, this scleractinian population is rapidly succumbing to competition with this stoloniferan octocoral (Alino 1989). Such overgrowth interactions are also pronounced in other scleractinian species in this section of Pandora Reef.

One of the reasons that Acropora has not become locally extinct here is that its vertical growth rate is roughly equivalent to that of Clavularia when involved in competition for space. Its refuge is its vertical growth rate. There is enough variance in growth rates in both species, however, that complete overgrowth and colony mortality in Acropora can be readily observed (Alino 1989). Actual whole-colony mortality of Acropora must require a reasonable amount of time, for although it may be readily observed in naturally occurring colonies, it was not observed in experimental colonies. There were indications, however, that such would eventually occur, given sufficient time.

Most of the coral species occurring on Pandora Reef are not branching in form, like Acropora longicyathus, and possess much slower growth rates - particularly the massive corals. This is most likely the reason for our common observations of total colony overgrowth in pairings between the octocorals used here and other scleractinians in the field (Fig. 2).

Competitive advantage of Clavularia over Acropora was reversed when interacting species pairs were 
transplanted to the mid-shelf. This was illustrated by the growth data and other indications of competitive interactions between the 2 species. Both species ceased growing on the mid-shelf, suggesting that the environmental setting was acting to the detriment of both. The ability of Clavularia to overgrow Acropora was countered by increased mortality in Clavularia due to predation on the midshelf. The pomacanthid Euxiphipops sextriatus was observed to be the major predator, causing relocated Clavularia colonies to all but disappear on Britomart Reef during the study.

Acropora, whether in competition or not, also suffered increased mortality on the mid-shelf. This was partially due to predation, primarily by chaetodontids. We believe that the increased levels of tissue bleaching and necrosis in Acropora transplanted to the midshelf may have been due to increased light levels. Midshelf waters possess much greater water clarity (Done 1982,1983 ) and allow transmission of both visible and UV light to greater depths than inshore waters (Smith \& Baker 1979, Jokiel 1980, Siebeck 1981, 1988, Drew 1983b, Kirk 1983, Dunlap et al. 1986). The high levels of mortality experienced by Acropora there may well have been due to local light conditions being above the threshold to which corals from Pandora Reef could acclimate. Higher-order interactions between competition, predation, and light adaptation in these 2 species appear to be complex and are presently being investigated experimentally (Alino \& Sammarco, work in progress).

Effects of predation were more easily documented in Acropora than Clavularia. This was due to the hard calcareous skeleton of the former producing a better record of predation through skeleton damage. Although the data showed Acropora as receiving a higher level of predation than Clavularia on the midshelf, the recorded levels of predation on Clavularia should be considered conservative here.

Briareum stechei emerged as the most robust species examined here. When competing for space with Acropora longicyathus in its natural habitat, it was clearly competitively superior. Not only did it easily overgrow the scleractinian, but its rate of progression was relatively constant with a low variance. In addition, it grew equally well when transplanted to the mid-shelf.

In almost all cases where Briareum was involved in transplant controls, there appeared to be evidence of significant side-effects due to handling. This was evident in both solo colonies and those involved in active competition for space. Changes significantly different from the natural controls were observed with respect to predation, overgrowth at the micro-scale, and bleaching of tissue. The cause of these changes, however, was not biological. Almost all of the substratum possessing Briareum suffered abrasion and damage due to storm waves, in particular due to Cyclone Winifred (Done et al. 1986), during the experiment. Apparently, Briareum is particularly susceptible to physical disturbance, more so than Acropora or Clavularia. Thus, data derived from any transplant controls using Briareum should be considered with this in mind.

The ability of Briareum to overgrow Acropora decreased when paired colonies were transplanted to the mid-shelf. This occurred despite the fact that noncompeting Briareum colonies (solo) grew at a faster rate on the mid-shelf than inshore. This supports the contention that the potential growth rate of a species does not necessarily determine its competitive capability (Lang \& Chornesky 1990), particularly under different environmental conditions. Other more complex competitive mechanisms, whether chemical or morphological, still determined the rate of colony progress over the competitor (Karlson 1983).

Acropora in competition with Briareum exhibited no growth when transplanted to the mid-shelf, for the reasons explained above. The increase in whole colony mortality and tissue necrosis was most likely due to a combination of competition from Briareum, increased light levels, and increased levels of fish predation (Alino \& Sammarco, work in progress). Briareum, on the other hand, exhibited no mortality or competitive weakness with respect to overgrowth, tissue necrosis, or bleaching - either under natural conditions or after relocation to the mid-shelf - when involved in active competition for space with Acropora. It also appeared to be immune to fish predation in either environment. It would appear that Briareum is actually better adapted to survive and grow on the mid-shelf than on inshore reefs.

Interactions between Briareum and Clavularia in their natural habitat were the most dynamic observed in this study. Although Briareum was competitively superior to Clavularia, there was a great deal of variance in their relative growth patterns in time and space. The competitive advantage of Briareum over both Clavularia and Acropora decreased when paired colonies were transplanted to the mid-shelf. This occurred despite the fact that the growth rate of Briareum was higher there. This further supports the premise that competitive ability is not necessarily determined by growth rate (Lang 1973). In this case, it was strongly influenced by the environment in which the competitive interaction was occurring.

Non-competing colonies of Briareum are well adapted to both inshore and mid-shelf waters. Noncompeting colonies of Clavularia were also well adapted to inshore waters. Upon being transplanted to the midshelf, however, Clavularia exhibited higher levels of mortality and predation, with a consequential reduction in growth rate. When the 2 corals are actively 
competing, Briareum is clearly superior in inshore waters. Given these data, one would expect to observe enhanced competitive superiority of Briareum over Clavularia in a mid-shelf environment; yet no significant competitive advantage was observed there (in terms of relative growth). This suggests that there are unknown factors associated with the new environment which may act synergistically to alter the expected outcome. Work in progress (Alino \& Sammarco) to isolate the effects of several of these factors suggests that the confounding factor may be a higher-order interaction between light and predation.

Both octocorals examined in this study exhibited a distinct competitive advantage over the scleractinian. This advantage appears to have been enhanced by present conditions in inshore waters of the central Great Barrier Reef. It appears that the octocorals and scleractinian corals previously coexisted in equitable abundances, because the reef exhibits normal rugosity, geomorphology and relief. The previously alive scleractinians now serve mostly as a substratum for soft coral growth in a number of sites on Pandora Reef.

The question arises as to what mechanism the octocorals may be using to assist them in competition for space, and in particular, what may be causing bleaching and tissue necrosis in the subordinate species. The 2 octocorals are known to possess biologically active secondary metabolites, including terpenoids (Alino 1989). Clavularia inflata is known to contain 2 sesquiterpenes (Alino 1989). Both the aqueous and organic crude extracts derived from this species are ichthyotoxic to test fish (sensu Yamanouchi 1955, Coll et al. 1982b). Although Briareum stechei contains a number of briarane-based diterpenoids, neither the aqueous nor organic crude extract derived from this species is ichthyotoxic.

Some gorgonians are known to produce sweeper tentacles when involved in competition for space (Sebens \& Miles 1988). Such tentacles were observed in Briareum during the course of this experiment (see Alino 1989). It is not possible from this experiment to determine whether the competitive advantage observed in Clavularia is conferred by allelopathy or morphological adaptations. It is highly probable, however, that competitive advantage in Briareum was due to its mat-like growth form and its ability to produce and utilise sweeper tentacles, much like Erythropodium sp. in the Caribbean (Karlson 1980).

La Barre (1984) and Alino (1989) provide information on the specific study site, demonstrating that Clavularia, Briareum, and Acropora longicyathus were dominant members of the benthic community on the northern side of Pandora Reef. Some other accounts of the natural abundances of the benthic community of Pandora Reef (Done 1982) are misleading, mainly because they provide only an overview of the scleractinian coral community for the entire reef. Unfortunately, they do not provide data on non-scleractinian coral benthos (including octocorals and zoanthids), and do not necessarily cover the sites used in this study.

Not all of Pandora Reef, of course, is covered by octocorals. Alino (1989) found that living cover in very shallow water ( 1 to $2 \mathrm{~m}$ ) on the northern face of Pandora Reef just above the study site was ca 80 to $90 \%$. It was ca $60 \%$ in the somewhat deeper area $(3$ to $5 \mathrm{~m}$ ) where the experiments were run. In the shallow reef flats, ca $95 \%$ of the living cover was composed of Clavularia inflata and the zoanthid Protopalythoa sp. Clearly, this depth zonation is indicative of the adaptation of different groups of organisms which survive and compete for space under different sets of physical conditions. The interactions noted in the experimental area pertain generally to that habitat.

It is not yet understood which characteristics of the inshore environment have changed to afford the octocorals increased competitive advantage. We suspect, however, that nutrient enrichment derived from terrigenous sources, introduced by runoff from the nearby Ross, Herbert, and Burdekin Rivers (Sammarco \& Crenshaw 1984), may be an important contributing factor. Risk et al. (1989) have traced terrigenous nutrients as a source of food for inshore corals of the northern Great Barrier Reef through $\delta^{13} \mathrm{C}$ and $\delta^{15} \mathrm{~N}$ ratios in scleractinian coral tissue. Similar and even stronger data are now emerging from this region (Risk et al. unpubl.). Wolanski \& Jones (1981) and Riddle (1988) also found evidence of increased nutrient concentrations and productivity in these inshore waters.

The outcome of interspecific competitive interactions can change, depending upon the environment in which they are occurring. Such interactions can be suppressed or reversed. The gradual domination of this habitat on Pandora Reef (inshore waters, Great Barrier Reef) by octocorals may be affected by a change in such environmental factors as nutrient enrichment and increased sediment load from coastal sources.

Acknowledgements. We thank A. G. Mackley, J. H. Carleton, and many excellent volunteers for their assistance in the field. We are also grateful to J. H. Carleton and A. G. Mackley for underwater photography, and to Ms E. Jeffery for assistance in data logging and analysis. We thank the crews of the RV 'Lady Basten' and RV 'Harry Messel' who helped make the field work possible. D. Alongi provided helpful comments on the manuscript. This research was supported by the Australian Marine Sciences and Technology Grants Scheme (MSTGS) and the Australian Institute of Marine Science. P. Alino is also grateful for the award of a James Cook University Postgraduate Fellowship from the MSTGS. 


\section{LITERATURE CITED}

Alino, P. M. (1989). Ecological and chemical aspects of interactions of soft corals (Octocorallia: Coelenterata). Ph.D. dissertation, Chemistry and Biochemistry, James Cook University of North Queensland, Townsville

Bak, R. P. M., Borsboom, J. L. A. (1984). Allelopathic interaction between a reef coelenterate and benthic algae Oecologia (Berlin) 63: 194-198

Bak, R. P. M., Termaat, R. M., Dekker, R. (1982). Complexity of coral interactions: influence of time, location of interaction, and epifauna. Mar. Biol. 69: 215-222

Bowden, B. F., Coll, J. C. (1983). Soft coral chemistry and its implications. In: Baker, J. T., Carter, R. M., Sammarco, P. W., Stark, K. P. (eds.) Proc. Great Barrier Reef Conf., Townsville. James Cook Univ. Press, Townsville, p. 281-285

Bradbury, R. H., Young, P. C. (1981). The effects of a major forcing function, wave energy, on a coral reef ecosystem. Mar. Ecol. Prog. Ser. 5: 229-242

Branch, G. M. (1984). Competition between marine organisms: ecological and evolutionary implications. Oceanogr. mar. biol. Ann. Rev. 22: 429-593

Buss, L. W. (1979). Habitat selection, directional growth, and spatial refuges: why colonial animals have more hiding places. In: Larwood, G., Rosen, B. R. (eds.) Biology and systematics of colonial organisms. Systematics Assoc. Spec. Vol. 11, Academic Press, New York, p. 459-497

Buss, L. W., Jackson, J. B. C. (1979). Competitive networks: nontransitive competitive relationships in cryptic coral reef environments. Am. Nat. 113: 223-234

Chan, A. T., Anderson, R. J., Le Blanc, J. J., Harrison, P. J. (1980). Algal plating as a tool for investigating allelopathy among marine microalgae. Mar. Biol. 59:7-13

Chornesky, E. A. (1989). Repeated reversals during spatial competition between corals. Ecology 70: 843-855

Coll, J. C., Bowden, B. F., Tapiolas, D. M., Dunlap, W. C. (1982a). In situ isolation of allelochemicals released from soft corals (Coelenterata: Octocorallia): a totally submersible sampling apparatus. J. exp. mar. Biol. Ecol. 60: 293-299

Coll, J. C., La Barre, S., Sammarco, P. W., Williams, W. T., Bakus, G. J. (1982b). Chemical defences in soft corals (Coelenterata: Octocorallia) of the Great Barrier Reef: a study of comparative toxicities. Mar. Ecol. Prog. Ser. 8: $271-278$

Coll, J. C., Sammarco, P. W. (1983). Terpenoid toxins of soft corals (Cnidaria: Octocorallia): their nature, toxicity, and ecological significance. Toxicon 1983, Suppl. 3: 69-72

Connell J. H. (1976). Competitive interactions and the species diversity of corals. In: Mackie, G. O. (ed.) Coelenterate ecology and behaviour. Plenum Press, New York, p. $51-58$

Connell, J. H. (1983). On the prevalence and relative importance of interspecific competition: evidence from field experiments. Am. Nat. 122: 661-696

Dinesen, Z. D. (1983). Patterns in the distribution of soft corals across the central Great Barrier Reef. Coral Reefs 1: $229-236$

Done, T. J. (1982). Patterns in the distribution of coral communities across the central Great Barrier Reef. Coral Reefs 1: 95- 107

Done, T. J. (1983). Coral zonation: its nature and significance. In: Barnes, D. J. (ed.) Perspectives on coral reefs. Austral. Inst. Mar. Sci., Brian Clouston Publ., Canberra, p. 107-147

Done, I. J., Moran, P. J., Devantier, L. (1986). Cyclone Winifred-observations on some ecological and geomorpholo- gical effects. In: Dutton, I. M. (ed.) The offshore effects of Cyclone Winifred. Proc. Workshop, 20 June 1986, Townsville, Qld. Great Barrier Reef Marine Park Authority Workshop Series No. 7, p. 50-51

Drew, E. A. (1983a). Halimeda biomass, growth rates, and sediment generation on reefs in the central Great Barrier Reef Province. Coral Reefs 2: 101-110

Drew, E. A. (1983b). Light. In: Earll R., Erwin, D. G. (eds.) Sublittoral ecology. The ecology of the shallow sublittoral benthos. Clarendon Press, Oxford, p. 10-57

Dunlap, W. C., Chalker, B. E., Oliver, J. K. (1986). Bathymetric adaptations of reef-building corals at Davies Reef, Great Barrier Reef Australia. III. UV-B absorbing compounds. J. exp. mar. Biol. Ecol. 104: 239-248

Gagan, M. K., Sandstrom, M. W., Chivas, A. R. (1987). Restricted terrestrial carbon input to the continental shelf during Cyclone Winifred: implications for terrestrial runoff in the Great Barrier Reef Province. Coral Reefs 6: $113-119$

Gagan, M. K., Johnson, D. P., Carter, R. M. (1988). The CYclone Winifred storm bed, central Great Barrier Reef shelf, Australia. J. sedim. Petrol. 58: 845-856

Hughes, T. P. (1986). Coral reef community structure following urchin mass-mortalities. Abstracts of the West. Soc. Nat., 67 th Ann. Meeting, Univ. Hawaii, Hilo, p. 27

Hughes, T. P., Reed, D. C., Boyle, M. (1987). Herbivory on coral reefs: community structure following mass mortalities of sea urchins. J. exp. mar. Biol. Ecol. 113: 39-59

Ikeda, T., Gilmartin, M., Revelante, N., Mitchell, A. W., Carleton, J. H., Dixon, P., Hutchinson, S. M., Hing Fay, E., Boto, G. M., Iseki, K. (1980). Biological, chemical, and physical observations in inshore waters of the Great Barrier Reef, North Queensland 1975-1978. Tech. Bull. Austr. Inst. Mar. Sci. (Oceanogr. Ser. No. 1) AIMS-OS-80-1. 56 p.

Jackson, J. B. C. (1977). Competition on marine hard substrata: the adaptive significance of solitary and colonial strategies. Am. Nat. 111: 743-768

Jackson, J. B. C., Buss, L. W. (1975). Allelopathy and spatial competition among coral reef invertebrates. Proc. natn. Acad. Sci. 72: 5160-5163

Jokiel, P. L. (1980). Solar ultraviolet radiation and coral reef epifauna. Science 207: 1069-1071

Karlson, R. H. (1980). Alternative competitive strategies in a periodically disturbed habitat. Bull. mar. Sci. 30: 894-900

Karlson, R. H. (1983). Disturbance and monopolization of a spatial resource by Zoanthus sociatus (Coelenterata, Anthozoa). Bull. mar. Sci. 33: 118-131

Karlson, R. H., Jackson, J. B. C. (1981). Competitive networks and community structure: a simulation study. Ecology 62 : $670-678$

Kirk, J T. O. (1983). Light and photosynthesis in aquatic ecosystems. Cambridge Univ. Press, Cambridge, p. 42-90

Klumpp, D. W., McKinnon, A. D. (1989). Temporal and spatial patterns in the productivity of coral reef epilithic algal communities. J exp. mar. Biol. Ecol. 131: 1-22

La Barre, S. C. (1984). Studies in the chemical ecology of alcyonarians (Coelenterata: Octocorallia). Ph.D. dissertation. Chemistry and Biochemistry, James Cook University of North Queensland, Townsville

La Barre, S. C., Coll, J. C., Sammarco, P. W. (1986). Defensive strategies of soft corals (Coelenterata: Octocorallia) of the Great Barrier Reef II. The relationship between toxicity and feeding deterrence. Biol. Bull. mar. biol. Lab., Woods Hole 171: 565-576

Lang, J. (1971). Interspecific aggression by scleractinian corals. 1. The rediscovery of Scolymia cubensis (Milne Edwards and Haime). Bull. Mar. Sci. 21: 952-959 
Lang, J. (1973). Interspecific aggression by scleractinian corals. 2. Why the race is not only to the swift. Bull mar Sci. 23: $260-279$

Lang, J. C., Chornesky E. A. (1990). Competition between scleractinian reef corals: a review of mechanisms and effects. In: Dubinsky, Z. (ed.) Coral reefs. Ecosystems of the World. Elscvicr Science Publ., Amsterdam, p. $209-252$

Levinton, J S. (1982). Marine ecology. Prentice Hall, Englewood Cliffs, New Jersey

McManus, J. W. Wenno, J. (1981). Coral communities of outer Ambon Bay: a general assessment survey. Bull. mar. Sci. 31:574-580

Muller, C. H. (1966). The role of chemical inhibition (allelopathy) in vegetational composition. Bull. Torrey Bot. Club 93: $332-351$

Revelante, N., Williams, W. T., Bunt, J. S. (1982). Temporal and spatial distribution of diatoms, dinoflagellates, and Trichodesmium in waters of the Great Barrier Reef. J. exp. mar. Biol. Ecol. 63: 27-45

Richardson, C. A., Dustan, P., Lang, J. C. (1979). Maintenance of living space by sweeper tentacles of Montastrea cavernosa, a Caribbean reef coral. Mar. Biol. 55: 181-186

Ricklefs, R. E. (1979). Ecology, 2nd edn. Chiron Press, New York

Riddle, M. J. (1988). Patterns in the distribution of macrofaunal communities of coral reef sediments on the central Great Barrier Reef. Mar. Ecol. Prog. Ser. 47: 281-292

Risk, M. J., Schwarcz, H. P., Sammarco, P. W., MacNeil, Y (1989). Preliminary report of a terrestrial component in the diets of Barrier Reef corals: implications for reef destruction and reef management. Great Barrier Reef Marine park Authority Workshop on Sediments in Nearshore Waters of the Great Barrier Reef, Great Barrier Reef Marine Park Authority, Townsville, p. 142-152

Russ, G. R. (1982). Overgrowth in a marine epifaunal community: competitive hierarchies and competitive networks. Oecologia (Berl.) 53: 12-19

Sammarco, P. W. (1983a). Coral recruitment across the central Great Barrier Reef: a preliminary report. In: Baker, J. T., Carter, R., Sammarco, P.W., Stark, K. (eds.) Proc. Great Barrier Reef Conf., James Cook University Press, Townsville, p. $245-251$

Sammarco, P. W. (1983b). Effects of fish grazing and damselfish territoriality on coral reef algae. I. Algal community structure. Mar. Ecol. Prog. Ser. 13: 1-14

Sammarco, P. W. (1991). Geographically specific recruitment and post-settlement mortality as influences on coral communities: the cross-continental shelf transplant experiment. Limnol. Oceanogr. 36: 496-514

Sammarco, P. W., Coll, J. C. (1988). The chemical ecology of alcyonarian corals (Coelenterata: Octocorallia). In Schever, P. J. (ed.) Bioorganic marine chemistry, Vol. 2 Springer-Verlag, Berlin, p. 87-116

Sammarco, P. W., Coll, J. C., La Barre, S., Willis, B. (1983) Competitive strategies of soft corals (Coelenterata: Octo-

This article was submitted to the editor corallia): allelopathic effects on selected scleractinian corals. Coral Reefs 1: 173-178

Sammarco, P. W., Coll, J. C., La Barre, S. (1985). Competitive strategies of soft corals (Coelenterata: Octocorallia): II Variable defensive response and susceptibility to scleractinian corals. J. exp. mar. Biol. Ecol. 91: 199-215

Sammarco, P. W., Crenshaw, H. (1984). Plankton community dynamics of the central Great Barrier Reef Lagoon: analysis of data from Ikeda et al. Mar. Biol. 82: 167-180

Sebens, K. P. (1986a). Community ecology and subtidal rock walls in the Gulf of Maine, USA: small scale processes and alternative community states. In: Moore, P. G., Seed, R. (eds.) The ecology of rocky coasts. Columbia University Press, New York, p. 346-371

Sebens, K. P. (1986b). Spatial relationships among encrusting marine organisms in the New England subtidal zone. Ecol. Monogr. 56: 73-96

Sebens, K. P., Miles, J. S. (1988). Sweeper tentacles in a gorgonian octocoral: morphological modification for interference competition. Biol. Bull. mar. Biol. Lab., Woods Hole 175: $378-387$

Sheppard, C. R. C. (1982). Coral populations on reef slopes and their major controls. Mar Ecol. Prog. Ser. 7: 83-115

Siebeck, O. (1981). Photoreactivation and depth-dependent UV tolerance in reef coral in the Great Barrier Reef/Australia. Naturwissenschaften 67: 426

Siebeck, O. (1988). Experimental investigation of UV tolerance in hermatypic corals (Scleractinia). Mar. Ecol. Prog Ser. 43: 95-103

Smith, R. C., Baker, K. S. (1979). Penetration of UV-B and biologically effective dose-rates in natural waters. Photochem. Photobiol 29: 311-323

Sokal, R. R., Rohlf, F. J. (1981). Biometry, 2nd edn. W. H. Freeman and Co., San Francisco

Sullivan, B., Faulkner, D. J., Webb, L. (1983). Siphonodictidine, a metabolite of the burrowing sponge Siphonodictyon sp. that inhibits coral growth. Science 221: $1175-1176$

Thompson, J. E. (1985). Exudation of biologically-active metabolites in the sponge Aplysina fistularis. I. Biological evidence. Mar. Biol 88: 23-26

Wahle, C. M. (1980). Detection, pursuit, and overgrowth of tropical gorgonians by milleporid hydrocorals: Perseus and Medusa revisited. Science 209: 688-691

Wellington, G. M. (1980). Reversal of digestive interactions between Pacific reef corals: mediation by sweeper tentacles. Oecologia (Berl.) 47: 340-343

Williams, D. M. (1982). Patterns in the distribution of fish communities across the central Great Barrier Reef. Coral Reefs 1: $35-43$

Wolanski, E., Jones, M. (1981). Physical properties of Great Barrier Reef lagoon waters near Townsville. I. Effects of Burdekin River floods. Aust. J. Freshwat. mar. Res. 32: 305-319

Yamanouchi, T. (1955). On the poisonous substance contained in holothurians. Publs Seto mar. biol. Lab. 4: 183-203

Manuscript first received: March 1, 1991

Revised version accepted: February 12, 1992 